\title{
TRANSFER, SIMILARITY OR LACK OF AWARENESS? INCONSISTENCIES OF GERMAN LEARNERS IN THE PRONUNCIATION OF LOT, THOUGHT, STRUT, PALM AND BATH ${ }^{1}$
}

\author{
ALEXANDER KAUTZSCH
}

University of Regenburg

\begin{abstract}
The current study presents acoustic analyses of non-high back vowels and low central vowels in the lexical sets LOT, THOUGHT, STRUT, PALM and BATH as pronounced by German learners of English. The main objective is to show that learners of English at university level are highly inconsistent in approximating the vowels of their self-chosen target accents British English (BrE) and American English (AmE). To that end, the acoustic qualities of the English vowels of learners are compared to their native German vowels and to the vowels of native speakers of $\mathrm{BrE}$ and $\mathrm{AmE}$. In order to facilitate statements about the effect of increased experience, the study differentiates between students in their first year at university and in their third year or later. The results obtained are highly variable: In some cases the learners transfer their L1 vowels to English, other cases show clear approximations to the target vowels, while other cases again document the production of new vowels neither found in German nor in English. However, close approximation to the target vowels only sometimes correlates with higher proficiency. This might be an indicator of a low level of awareness of systematic differences between the $\mathrm{BrE}$ and $\mathrm{AmE}$ vowel systems. But the data also indicate that the more advanced learners produce more distinct AmE BATH vowels and BrE THOUGHT vowels than the less advanced learners, which points to a partial increase of awareness resulting from increased experience. All in all it seems that raising the awareness of differences between target accents in L2 instruction is necessary if the envisage goal is for learners to reach near-native pronunciation.
\end{abstract}

\section{Introduction}

In varieties of English around the world words of the lexical sets LOT, THOUGHT, and BATH are pronounced in different ways. This leads to different degrees of overlap with the lexical sets PALM and STRUT.

In the two major varieties of English which German learners aim at, namely BrE and AmE, these differences manifest themselves as shown in table 1.

1 I would like to thank one anonymous reviewer for helpful comments on this paper. All remaining shortcomings are my own responsibility. 


\begin{tabular}{|c|c|c|c|}
\hline Lexical set & Example & BrE & $\mathbf{A m E}$ \\
\hline LOT & body & ['bodi] & ['ba(:)di] ['bo(:)di] \\
\hline THOUGHT & raw & [ro:] & {$[\mathrm{ra}(\mathrm{s})] \sim[\mathrm{ro}(\mathrm{i})]$} \\
\hline BATH & dance & [da:ns] & [dæns] \\
\hline PALM & father & ['fa:ðə] & ['fa(:)ठə] \\
\hline STRUT & run & {$[\mathrm{r} \wedge \mathrm{n}]$} & {$[\mathrm{r} \wedge \mathrm{n}]$} \\
\hline
\end{tabular}

Table 1: Examples for BrE and AmE pronunciation of the lexical sets LOT, THOUGHT, BATH, PALM, and STRUT

The LOT and THOUGHT vowels are less rounded in AmE than in BrE and can be variable in quantity, as indicated by "(:)" in table 1 (cf. Wells 1982: 120, 122, 124, 476). Many native speakers of AmE merge THOUGHT and LOT either to [o(:)] or to [a(:)] (cf. Wells 1982: 473-476). A short and low AmE pronunciation of LOT / THOUGHT is very similar to STRUT. The BATH vowel matches with PALM in BrE, with TRAP in AmE. Similar to LOT and THOUGHT, AmE PALM can be comparatively short. (cf. Wells 1982: 118-124).

It could be hypothesized that for learners of English who are not aware of these differences between and variability within varieties of English and perceive the language they are learning as a monolithic whole, these multiple pronunciations of mid and low back vowels and low central are likely to be interpreted as a highly variable model. As a result, learners are inconsistent in targeting their self-chosen accent, making use of a plethora of vowels from different models. ${ }^{2}$

Along these lines, the present paper studies German learners of English at university level, mostly students in teacher training. It sets out to describe and interpret their inconsistencies in the production of vowels in the lexical sets LOT, THOUGHT, STRUT, PALM and BATH with respect to the learners' self-chosen target accents, in this case either BrE and AmE. Such an interpretation needs to take into account the notions of interlanguage, L1 transfer, similarity, and awareness.

In the case of the English vowels in LOT, THOUGHT, STRUT, PALM and BATH as pronounced by German learners of English similarity to the German vowels SOCKEN, BOTEN, HATTEN, and BATEN might be expected to lead to transfer, especially since these vowels receive little attention in formal instruction.

However, the acoustical analyses presented here show that in many cases learners use sounds different from both L1 and L2, which can be seen as an empirical manifestation of interlanguage. The likely reason for the learners' inconsistencies, therefore, cannot be pinned down to transfer alone, but also to a lack of awareness of the highly heterogeneous nature of the input around them.

\footnotetext{
2 Even if this might be, according to the anonymous reviewer, an "unwarranted assumption", it is a reasonable one. Unfortunately, no previous studies supporting this claim could be discovered.
} 


\section{English and German non-high back and low central vowels}

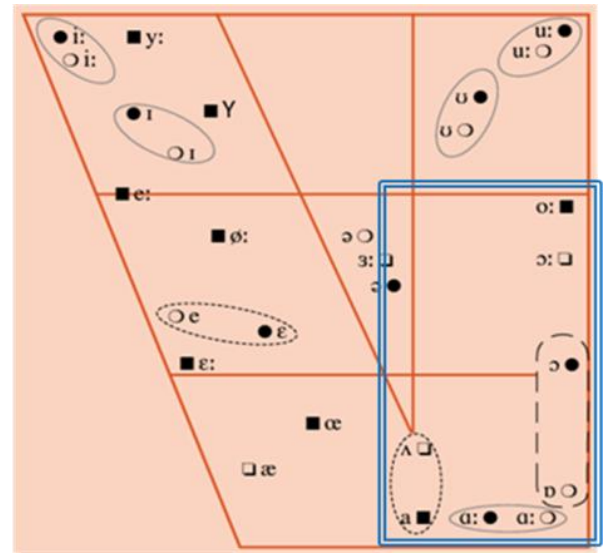

Figure 1: The vowels of English (RP) and German (taken from Kortmann 2005:182)

Figure 1 provides a contrastive overview of the vowel systems of English (RP) and German. The vowels to be dealt with in the present study, viz. the non-high back vowels and the low central vowels, are highlighted by the box.

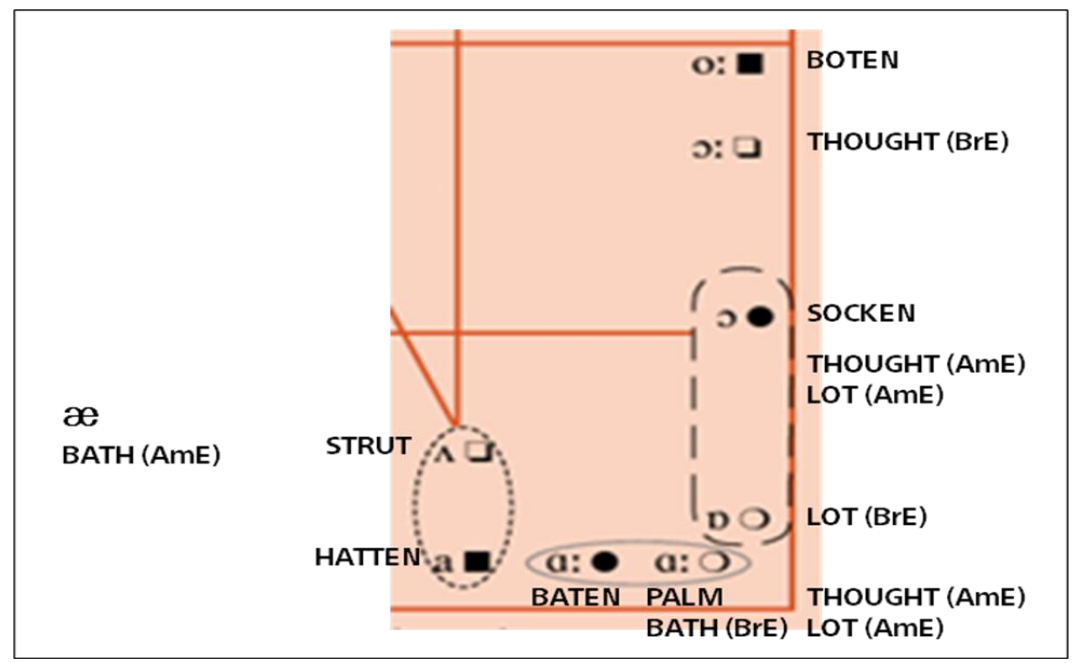

Figure 2: Non-high back vowels and low central vowels of English (RP) and (adapted from Kortmann 2005:182)

Figure 2 zooms into the relevant area and roughly places lexical sets for German, BrE and AmE at the traditional articulatory locations of vowels.

The four German vowels are represented by BATEN, HATTEN, BOTEN and SOCKEN. The BATEN and HATTEN vowels are long and short low central vowels, 
respectively, with HATTEN being slightly fronter than BATEN. BOTEN and SOCKEN are long and short mid back vowels, respectively, with BOTEN being considerably closer than SOCKEN.

American and British STRUT and PALM are close to German HATTEN and BATEN. British THOUGHT is close to German BOTEN, the American versions are more open and less rounded, and can be as open as to match PALM. British LOT is, from an articulatory perspective, the rounded counterpart of [a], American LOT is less rounded and its variants can be very similar to those of THOUGHT (LOT-THOUGHT merger, cf. Wells 1982: 473-476).

In BATH BrE uses the same vowel as in PALM, while the AmE BATH vowels equals TRAP and is realized as [æ].

The following section briefly surveys relevant concepts of SLA theory and makes some predictions of possible problems and routes of transfer in the acquisition of the vowel systems of BrE and AmE by German learners.

\section{SLA theory: L1 transfer, similarity and awareness}

On the basis of the differences between German and English vowel space mentioned above, the present section will briefly discuss the notion of interlanguage in connection with L1 transfer in L2 phonological acquisition and suggest that the outcome of L2 phonological acquisition is very likely to be connected to the level of awareness learners have for the details of the sound system of their target accent.

Interlanguage as introduced by Selinker (1972) entails the widely accepted notion that learners when acquiring a second or foreign language "create a language system", which is not seen as a "deficit system [...] but as a system of its own with its own structures" (Gass and Selinker 2008: 14). The elements of the interlanguage are either from the learner's L1 or from the L2. In addition there are so-called "new forms", elements that belong neither to the L1 nor to the L2 (ibid.).

The process responsible for L1 elements being present in the L2 is L1 transfer. Especially in L2 phonological acquisition L1 transfer is, despite its behaviourist roots, a well accepted concept (cf. Major 2008 for a detailed discussion).

What often goes hand in hand with L1 transfer is the notion of cross-linguistic similarity in that it addresses "the question which phenomena are more susceptible to transfer and which are not" (Major 2008: 71). Here most researchers agree that "[t]he more similar the phenomena the more likely transfer will operate; however, what constitutes similar is not always clear-cut" and "a more rigorous and universally agreed upon definition of similarity would seem necessary (Major 2008: 74).

Along these lines Bohn (2002) states that "[a]rmchair methods and acoustic and articulatory comparisons can, at best, serve as a starting point" (Bohn 2002:209) and according to Strange (2007) "[c]ross linguistic similarity is difficult to measure without perception data" (Strange 2007: 45). In other words, the only reliable way to define 
similarity is through perception experiments (cf. Strange 2007, Bohn 2002, Strange and Shafer 2008). ${ }^{3}$

In this vein the acoustic data presented here will serve as a starting point for the description of L2 phonological acquisition of learners faced with more than one model. But they will also serve to support the claim that similarity is a highly relative concept. Equivalence classifications of sounds on the basis of assumed similarities are subconscious processes of which learners are not aware. It seems to be necessary to see similarity in Major's (2008: 75) terms as slowing down acquisition, but to different extents and on an individual basis.

Two examples from L1 German L2 English learners will serve to illustrate this. It has been shown elsewhere (Kautzsch 2010a) that in the case of the English mid and low front vowels [e] and [æ] in bed and bad (i.e in the lexical sets DRESS and TRAP) German has only one short vowel counterpart $[\varepsilon]$ as in BETTEN, which is then - due to equivalence classification - used in both English contexts. The distinction between [e] and $[æ]$ develops quite late in German learners. This is very likely due to the fact that this distinction does not feature prominently in German ESL/EFL classrooms, resulting in a low level of awareness for this difference. ${ }^{4}$

In the case of the dental fricatives $/ \theta /$ and $/ ð /$, which due to their absence in German could be seen as dissimilar and therefore should be easier to acquire, the relativity of similarity becomes even more apparent. The success rate of German learners here is much higher, although there remain a considerable number of learners who do not manage to acquire these sounds and use the alveolar fricatives [s] and [z] instead. From a similarity perspective this means that for those learners who succeed in the acquisition, the dental fricatives are dissimilar enough from German sounds as not to be classified as equivalent. For those who fail, a perceived similarity with alveolar fricatives persists. Again, the different performances of these learners seem to be connected to awareness. As soon as one is aware of two sounds being different, they become more dissimilar and are thus acquired faster. And since much emphasis is placed on the dental fricatives in ELT in Germany, a higher level of awareness is created and the approximation to the target sound is on the whole more successful.

The notion that learners can be made aware of similar phenomena is not new in SLA. It is inherent, for example, in "Focus on Form" (presented for example in ch. 11.5 in Gass and Selinker 2008), or in the "Noticing Hypothesis" (developed by Schmidt in a series of articles on attention and awareness: Schmidt 1990, 1994, 1995, 2001, 2010). Making learners aware of certain structures (or in our case sounds) seems especially applicable in the classroom, less so in natural, immersive settings (cf. Krashen 1985, Gass and Selinker 2008).

As far as the vowels under scrutiny in the current study are concerned, they receive little attention in the ESL/EFL classroom of German learners of English. And when

\footnotetext{
${ }^{3}$ For three popular models which incorporate similarity as a central concept see the Speech Learning Model (Flege 1995), the Perceptual Assimilation Model (Best and Strange, 1992; Best 1994, 1995) and the Native Language Magnet model (Kuhl 1993, 1991).

${ }^{4}$ A similar situation is reported upon in Kautzsch (2010b) where German learners of English are very inconsistent in their realizations of non-prevocalic $r$ when aiming at $\mathrm{BrE}$ or AmE.
} 
considering Schmidt and Frota's (1986) claim that "a second language learner will begin to acquire the target like form if and only if it is present in comprehended input and 'noticed' in the normal sense of the word, that is consciously", it must be assumed that German learners will have difficulties in acquiring the vowels in LOT, THOUGHT, BATH, STRUT, and PALM; transfer will possibly be at work to some extent.

\subsection{Predictions for German learners of English}

Based on the cross-linguistic analysis above, the present section will make some predictions for the acquisition of a BrE and an AmE vowels system by German learners.

For German learners of English aiming at BrE the German and English non-high back vowels and low mid central vowels are similar in their articulatory properties and in their relative positions, i.e. the German system has the same contrasts as the BrE system, namely a pair of short and long mid back vowels, and a pair of short and long low central vowels. Thus it would be easy for German learners aiming at BrE to apply German BATEN, HATTEN, BOTEN and SOCKEN in English PALM/BATH, STRUT; THOUGHT, and LOT, respectively. In other words, L1 transfer can be expected, but at the same time few inconsistencies will arise since the two systems contain the same distinctions.

For students aiming at AmE there are several options to utilise their German vowels in English. HATTEN and BATEN may be matched with STRUT and PALM, but BATEN might also be used in THOUGHT and LOT, if pronounced as a very open vowel $[a(:)]$. Alternatively, when THOUGHT and LOT are pronounced as $[o(:)]$, the SOCKEN or BOTEN vowel is likely to occur. However, BOTEN being a rounded close mid vowel, it is also possible that it is not employed at all. SOCKEN, on the other hand, may turn out to be too short to be used in LOT and THOUGHT. Thus, if LOT and THOUGHT are not pronounced similar to $[a(:)]$, learners need to acquire a new sound. The same applies to the BATH vowel, which needs to be matched with TRAP and pronounced as [æ], a new sound that does not belong to the German vowel inventory. In sum, it seems that the acquisition of the AmE system is more inconsistency-prone than the acquisition of the BrE system.

\section{Data}

The learners analyzed in this study are 20 students of English from the University of Regensburg. All have been chosen on the basis of a stable L1 background, i.e. they were born and raised in two adjacent regions of Bavaria, the south-eastern of the federal states of Germany: the Upper Palatinate (Oberpfalz) and Lower Bavaria (Niederbayern).

10 students each have AmE and BrE as their self-chosen target accent. Each of the target accent groups contains two proficiency levels: 5 learners each are "beginners" (Beg), i.e. students of English in their first year at university, and "advanced" students $(\mathrm{Adv})$, i.e. learners in their $3^{\text {rd }}$ year of later. What matches proficiency in this sample is the students' average time spent abroad in months: the beginners have spent 0.8 months 
in an English speaking country, while the advanced students have been abroad for 8.3 months.

The analyses below will provide insights into how successful German learners of English are in approximating their self-chosen target accent and if they become more successful as proficiency and time spent abroad increases.

\section{Method}

The acoustical analysis to follow (section 6) will present the learners' English and German vowels and contrast them to BrE and AmE native speaker control groups.

The learners' vowels were elicited by means of reading two word lists, the one consisting of all English monophthongs, two from each lexical set, the other containing all German monophthongs. The present study picks out non-high back vowels and low central vowels as represented by the words below, the whole database thus totalling 200 English and 80 German monophthongs:

\begin{tabular}{ll} 
- & body, cot (LOT) \\
- & bawd, caught (THOUGHT) \\
- & bud, cut (STRUT) \\
- & bather, palm (PALM) (BATH) \\
- & Socken (SOCKEN) \\
- & Boten (BOTEN) \\
- & hatten (HATTEN) \\
\hline
\end{tabular}

The wordlists educe the speakers' most monitored style and therefore provide access to their idealized targets. The recordings were made in a quite office setting, vowels were measured at the centre using Praat (Boersma and Weenink no date) and plotted by means of Kendall and Thomas's (2010) "vowels" package for "R" (The R Project for Statistical Computing no date), applying auditory-based Bark measure ${ }^{5}$ for normalization to even out individual differences across speakers.

For the comparison with native speaker data, formant values published in two previous studies are utilised: The AmE vowels are taken from Hillenbrand et al. (1995), who analyse 45 men, 48 women $^{6}$ from Michigan (Great Lakes / Midland). The BrE vowels are taken from Deterding $(1997,1990)$, who provides the vowels of 8 men and 8 women from the South of England. In both studies, participants read lists of words in the context h_d ${ }^{7}$.

5 For further details on Bark normalization and the resulting $Z$ values (cf. figures 3 to 10) see Thomas and Kendall (2007: "Methods") and Traunmüller (1997).

${ }^{6}$ Hillenbrand et al. (1995) also measure the vowels of children, but the present analysis only adopts the vowels of adults.

${ }^{7}$ Some scholars call for stable phonetic contexts when analysing vowels, because of variable coarticulation effects (cf. e.g. Bohn 2002:199). Others only avoid "tokens following the approximants $[\mathrm{w}],[\mathrm{j}]$ and $[\mathrm{r}]$ " and tokens "before [ $\mathrm{y}]$ and dark [1], as all these sounds have severe coarticulatory effects on the vowel" (Deterding et al. 2008: 162). 


\section{Results}

The results will be presented by means of two vowel plots for each of the learners' selfchosen target variety, for $\mathrm{BrE}$ in 6.2 , for $\mathrm{AmE}$ in 6.3. The first plot in each section contains the average locations of the vowels as produced by the beginners and the advanced students to documents differences in the two proficiency groups. In addition these plots provide the average locations of the native speakers' vowels to illustrate the learners' degree of approximation to their target.

The second plot in each section adds the average locations of the learners' German vowels in order to obtain a visual idea of the degree of L1 transfer taking place, i.e. to show to what extent German learners use their native vowels in English.

\subsection{British English Target}

Figure 3 shows the results for beginners and advanced learners aiming at $\mathrm{BrE}$ in comparison to BrE native speakers. Advanced students are closer to native THOUGHT than the beginners (circle 1 in Figure 3 ). The LOT vowels (circle 2) are very close to native LOT for both groups. With the lexical sets STRUT, BATH and PALM, beginners are closer to native vowels (circle 3), while advanced students display a stronger somewhat unnecessary - differentiation between these vowels (circle 4).

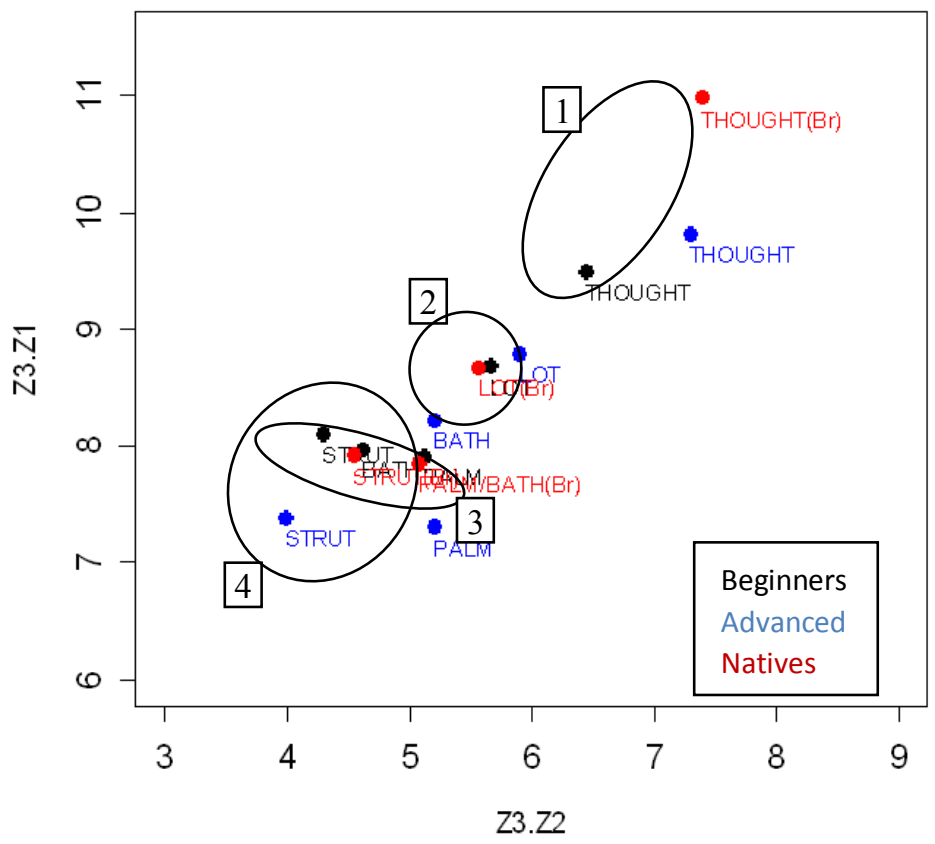

Figure 3: The BrE non high back vowels and low central vowels of German beginners and advanced learners and of native speakers of BrE 
Adding the German vowels to the plot (Figure 4) results in the following picture: German SOCKEN (circle 1) is not used for LOT (circle 2), German BOTEN is very close to native THOUGHT but produce different vowels (circle 3), the pronunciation of STRUT and PALM is close to German HATTEN and BATEN for advanced students (circle 4), while the beginner's pronunciation of STRUT/PALM/BATH is closer to that of native speakers (circle 5). The advanced group's BATH vowel is considerably higher (circle 6).

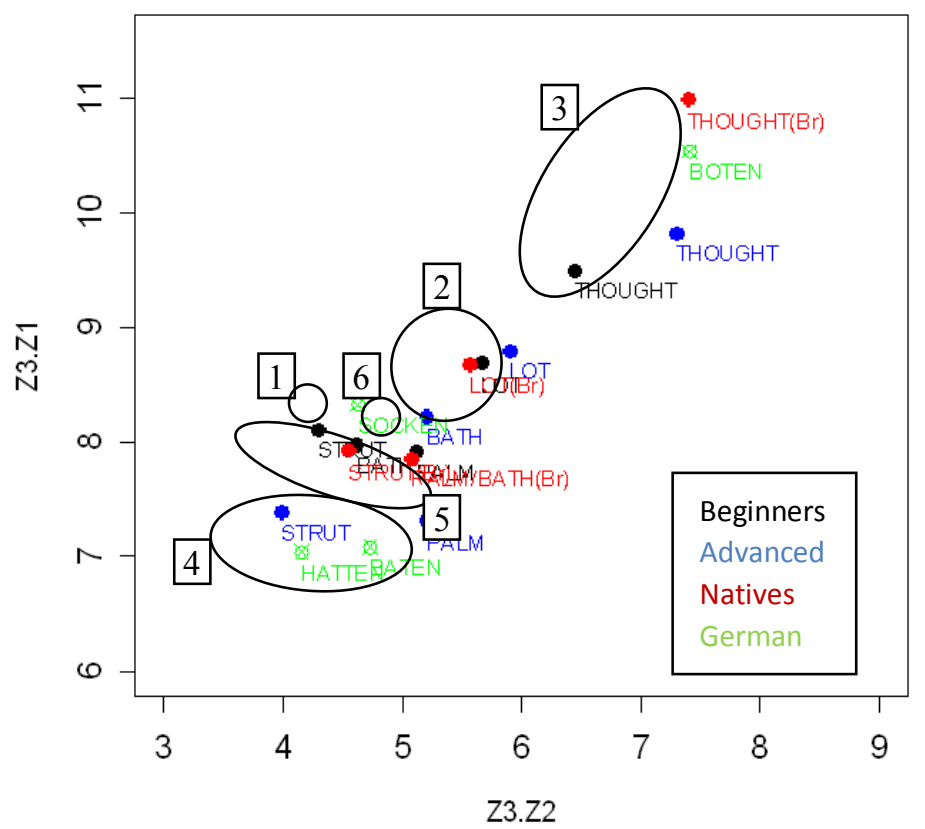

Figure 4: The BrE and German non high back vowels and low central vowels of German beginners and advanced learners, and the $\mathrm{BrE}$ non high back vowels and low central vowels of native speakers of $\mathrm{BrE}$

Summing up, German high proficiency learners acquire the LOT vowel as a close approximation to native LOT and do not transfer German SOCKEN. Although German BOTEN is close to BrE THOUGHT, German learners use a different vowel, which is more open on average. In the case of PALM, BATH and STRUT, beginners are very close to the BrE target vowels, while advanced students' PALM and STRUT are closer to their native BATEN and HATTEN.

Thus, the predictions that German high proficiency learners aiming at BrE use their native vowels BATEN, HATTEN, BOTEN and SOCKEN in English cannot be confirmed; in other words expected L1 transfer take place to a limited extent only.

In addition, the increased experience of advanced students as opposed to beginners does not increase their approximation to target vowel sounds, in fact the beginners are closer to the target vowels in the case of PALM, BATH and STRUT. 


\subsection{American English Target}

The results for German learners' non-high back and low central vowel with respect to an AmE target and in comparison to native speakers of AmE are shown in figure 5.

Both the beginners and the advanced students produce a close approximation to native THOUGHT and LOT, with the beginners being even closer (circles 1 and 2 in figure 5). The learners' BATH vowel is very different from native BATH; here the advanced students are closer to native BATH but still at considerable distance (circle 3). Moreover, German learners produce different vowels for LOT and PALM (circle 4). Finally, the learners' STRUT vowels are considerably lower than native STRUT (circle 5), with the beginners being close to native LOT. This mismatch between native and non-native STRUT, however, needs to be interpreted with caution. It cannot be seen as a failure to approximate a native target on the side of the learners. It rather results from the control groups' origin in the Greater Lakes region in the US. This is the area which is likely to have been in the initial stage of the Northern Cities Vowel Shift (cf. Labov et al. 2006: 187-208) at the time of recording and thus the speakers' pronunciation of STRUT does not represent a familiar target for learners. What this also illustrates is the theoretically and practically challenging situation of multiple and heterogeneous target accents.

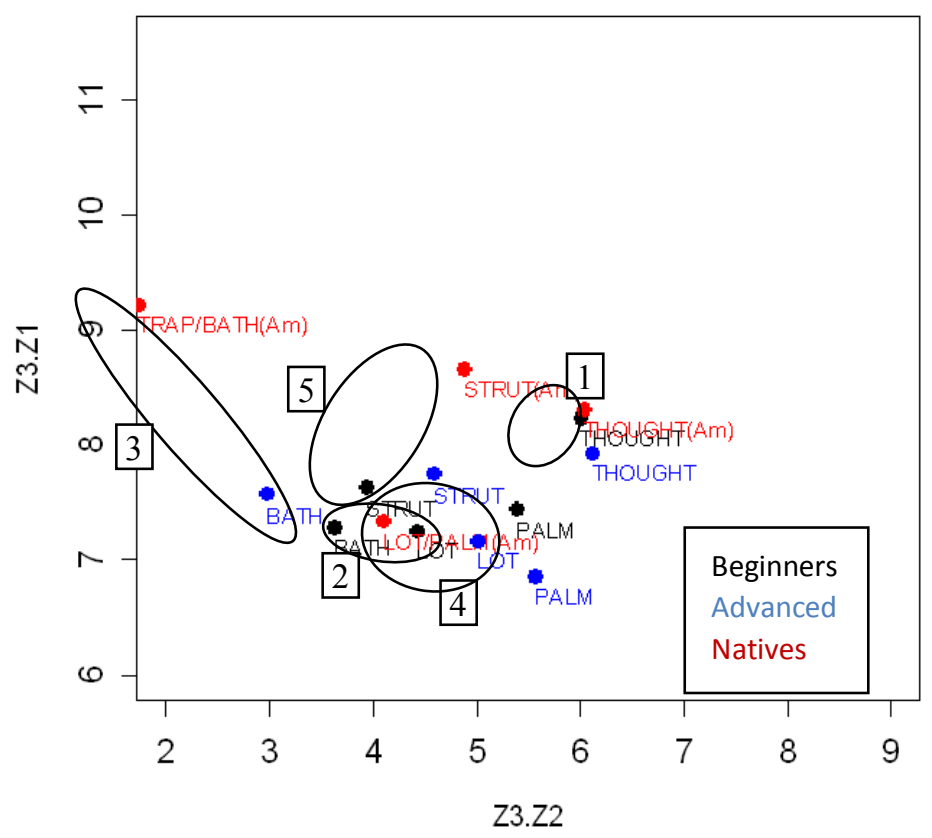

Figure 5: The AmE non high back vowels and low central vowels of German beginners and advanced learners and of native speakers of $\mathrm{AmE}$

Adding the German vowels to the plot (figure 6) once more gives some insight into possible L1 transfer. BOTEN and SOCKEN are not used in the learners' English (circles 
1 and 2). The learners' LOT vowels, as well as native LOT, are similar to BATEN/HATTEN (circle 3). THOUGHT, on the other hand, is a new native-like sound (circle 4), while BATH (circle 5), PALM (circle 6) and STRUT (circle 7) are new sounds which are neither German nor AmE.

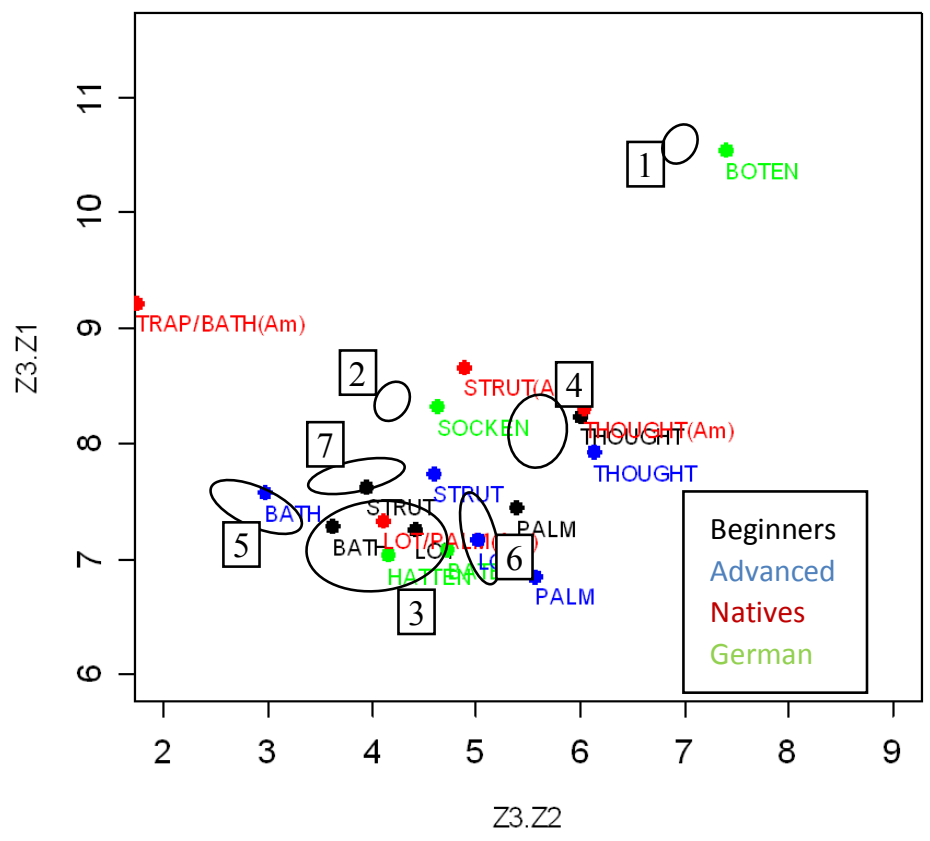

Figure 6: The AmE and German non high back vowels and low central vowels of German beginners and advanced learners, and the $\mathrm{AmE}$ non high back vowels and low central vowels of native speakers of $\mathrm{AmE}$

Summing up, the only AmE vowel of German learners in which some degree of L1 transfer can be witnessed is the LOT vowel. It is close to German BATEN/HATTEN and learners make use of this proximity.

With AmE THOUGHT all learners use a vowel close to the target and different from German vowels, whereas in the cases of AmE BATH, PALM, and STRUT all learners use sounds different from German and AmE. In addition both learner groups maintain an (unnecessary) distinction of PALM and LOT. German BOTEN and SOCKEN, on the other hand, are not transferred. Similar to the learners aiming at BrE, increased experience on the side of the advanced students does not increase their approximation to the target.

\subsection{Individual variation}

In addition to the average locations of non-high back vowels and low central vowels as presented above (6.1 and 6.2), this section shows four vowel plots to illustrate variation 
across speakers. The plots are again grouped by target accent and each accent group has one plot for beginners and one for advanced students. The ellipses around the mean values mark the acoustical ranges of the respective vowels.

Starting with the results for the BrE group, the beginners' vowels (figure 7) overlap to different extents than the advanced students' vowels (figure 8).

With the beginners, larger areas of STRUT and BATH overlap, PALM almost completely covers the area of STRUT, BATH and LOT, which results from some mispronunciations of PALM as [po:m]. Both BATH and STRUT overlap slightly with LOT, and so does THOUGHT with LOT.

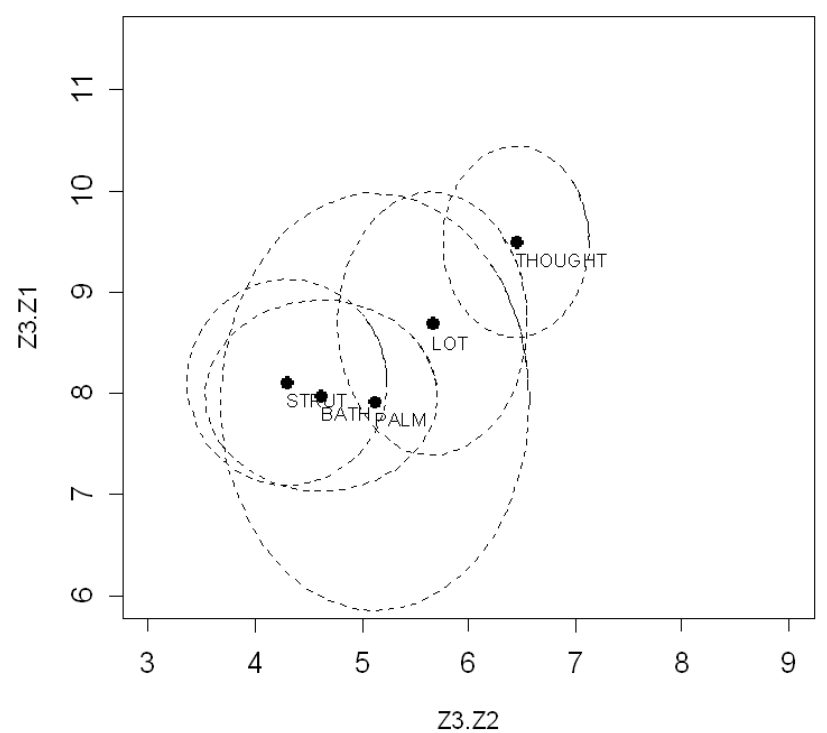

Figure 7: Beginners' individual variation in the pronunciation of BrE non-high back vowels and low central vowels.

The plot for the advanced students again shows the clearer distinction between PALM, STRUT and BATH mentioned above (6.1., figures 3 and 4). As a consequence, a wider area of vowel space is covered. This, however, does not result in a clear distinction between these vowels but rather leads to multiple overlaps of STRUT, PALM, BATH, and LOT. A noticeable difference between the beginners and the advanced students can be observed with respect to THOUGHT, which is almost completely distinct from LOT. 


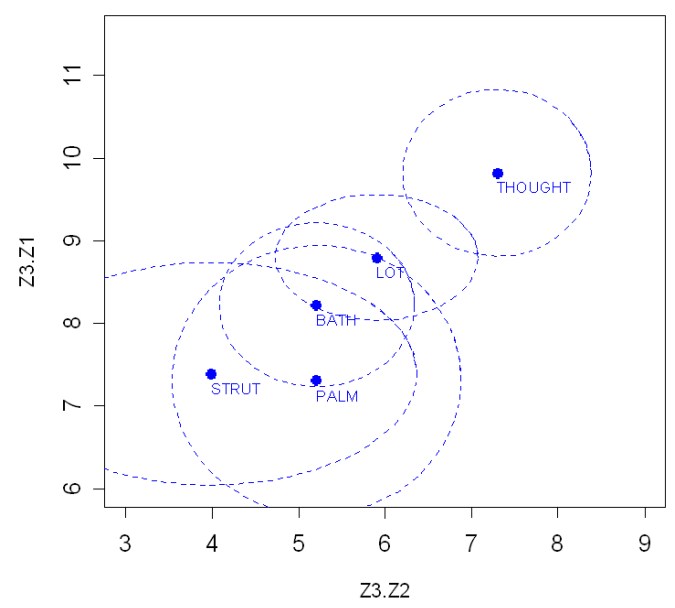

Figure 8: Advanced students' individual variation in the pronunciation of $\mathrm{BrE}$ non-high back vowels and low central vowels

Individual variation in the AmE target groups is shown in figures 9 (beginners) and 10 (advanced students). THOUGHT is almost fully distinct in both groups, overlapping to small extents with LOT in the advanced group and with PALM in both groups, the latter again being due to mispronunciations of PALM. In addition, both groups share a considerable overlap of LOT, STRUT and PALM. The evident difference between beginners and advanced students is that advanced students have a fully fronted version of BATH, fully distinct from LOT, STRUT, and PALM, whereas beginners' BATH strongly overlaps with these vowels.

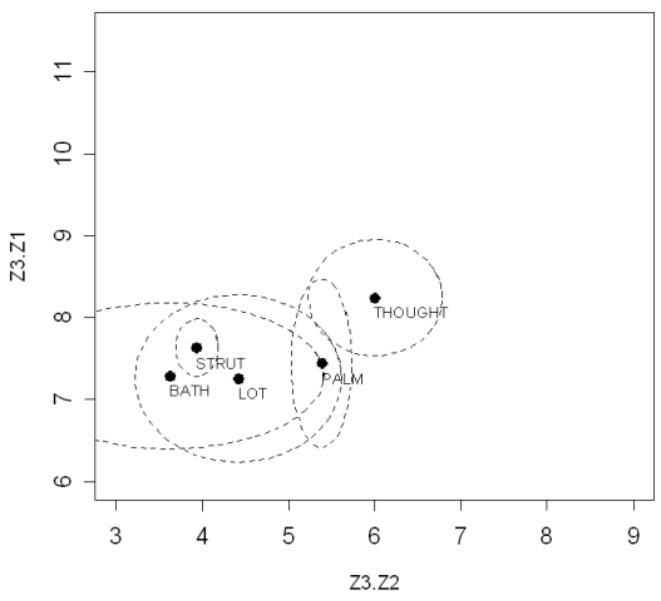

Figure 9: Beginners' individual variation in the pronunciation of AmE non-high back vowels and low central vowels 


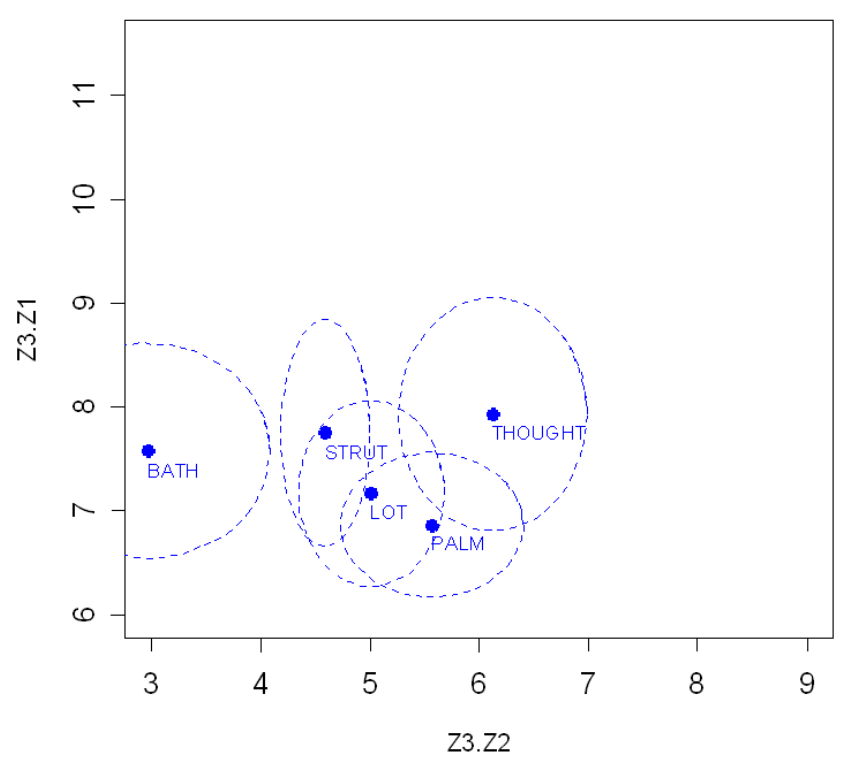

Figure 10: Advanced students' individual variation in the pronunciation of AmE non-high back vowels and low central vowels

In sum, this section has shown that the pronunciation of the vowels under scrutiny by German learners varies to a considerable extent, indicating that it seems difficult for learners to acquire a consistent and contrastive system, even after more than 10 year of instruction and some time spent abroad. In two cases, however, a differentiation of the vowel systems could be documented with the advanced students: THOUGHT becomes more distinct from LOT in the BrE system and BATH from STRUT/PALM/LOT in the AmE system. The overlaps and differentiations in the vowel systems under observation point to the fact that learners do make some progress in approximating a self-reported target accent with some vowels as proficiency increases, but fail to do so with others. A likely explanation might again be awareness. It is easy to picture that with greater experience in the foreign language, learners perceive a fronted version of BATH and a rounded and closer version of THOUGHT as symbols of AmE and BrE, respectively, and start to use these variants. Other characteristics, however, seem to go unnoticed.

\section{Summary and Conclusions}

The acoustical study of the mid and low back vowels and the low front voelws of 20 German learners of English at university level has yielded the following overarching results:

1. When targeting AmE or BrE non-high back vowels and low central vowels, German learners of English at university level make only little use of their native vowel systems. In other words, they are beyond a stage of strong L1 transfer. 
2. The learners produce new vowels which are neither native German nor native English, which is a clear support for the reality of interlanguage as a system that, among other things, also contains "elements [...] that do not have their origin in either the NL or the TL" (Gass and Selinker 2008: 14).

3. Increasing experience in term of a closer approximation to the target is only reflected in two cases: BATH is more front in advanced learners aiming at AmE and THOUGHT is closer in advanced learners aiming at BrE. This might be due to an increased level of awareness of these vowels as a result of increases experience.

4. In general, however, experienced learners are not more native-like than less experienced learners with respect to the vowels under discussion after more than 10 years of learning.

All in all, the data presented here indicate that the learners of English analysed have not fully acquired an L2 sound system. Having demonstrated that only two very salient vowels start to be acquired at an advanced stage of proficiency, it seems that near-native pronunciation can only be acquired or learned - if at all - with attention to and awareness of the variability of the input ${ }^{8}$. Even experienced learners have no full awareness of the systematic differences between the two major accents of English. If near-nativeness in pronunciation is the envisaged goal of language learning, it is necessary to integrate awareness of varieties of English into the ESL/EFL classroom, and especially in teacher training at universities.

\section{References}

Best, C. and W. Strange. 1992. "Effects of phonological and phonetic factors on crosslanguage perception of approximants". Journal of Phonetics 20: 305-331.

Best, C. 1994. "The emergence of native-language phonological influence in infants: A perceptual assimilation model." In H. Nusbaum, J. Goodman and C. Howard, eds. The Transition from Speech Sounds to Spoken Words: The Development of Speech Perception. Cambridge, Mass.: MIT Press, 167-224.

Best, C. 1995. "A direct realist view of cross-language speech perception." In Strange, ed. 1995: 171-204.

Boersma, P. and D. Weenink. No date. "Praat: Doing phonetics by computer". [www.praat.org; accessed 31/06/2011] .

Bohn, O.-S. 2002. "On phonetic similarity". In P. Burmeister, T. Piske and A. Rohde, eds. An Integrated View of Language Development. Trier: WVT, Wissenschaftlicher Verlag Trier, 191-216.

Deterding, D. 1990. "Speaker Normalization for Automatic Speech Recognition". Ph.D.Thesis, Cambridge University.

\footnotetext{
${ }^{8}$ I fully agree with the anonymous reviewer that "[j]ust because less salient vowel qualities weren't learned it doesn't follow that near-native pronunciation would be possible even with attention to and awareness of the variability of the input". As usual in science, future research will shed more light on this issue.
} 
Deterding, D. 1997. "The Formants of Monophthong Vowels in Standard Southern British English Pronunciation". Journal of the International Phonetic Association 27: 47-55.

Deterding, David, Jennie Wong and Andy Kirkpatrick. 2008. "The pronunciation of Hong Kong English". English World-Wide 29(2): 148-175.

Flege, J. E. 1995. "Second language speech learning: Theory, findings, and problems". In Strange, ed. 1995: 233-277.

Gass, S. M. and Selinker, L. 2008. Second Language Acquisition: An Introductory Course ( $3^{\text {rd }}$ ed.). New York and London: Routledge.

Hansen Edwards, J.G. and M.L. Zampini, eds. 2008. Phonology and Second Language Acquisition. Amsterdam and Philadelphia: John Benjamins.

Hillenbrand, J., L. A. Getty, M. J. Clark and K. Wheeler. 1995. "Acoustic characteristics of American English vowels". Journal of the Acoustical Society of America 97(5):3099-3111.

Kautzsch, A. 2010a. "Exploring L1 transfer in German Learners of English: High front vowels, high back vowels and the $\mathrm{BED} / \mathrm{BAD}$ distinction." Research in Language (Special Issue: Proceedings of ACCENTS 2009, Lodz) 8: 63-84.

Kautzsch , A. 2010b. Rhoticity in German Learners of English. Paper presented at World Englishes 2010 in Vancouver, Canada, August 2010.

Kendall, T. and E.R. Thomas. 2010. "Vowels: Vowel Manipulation, Normalization, and Plotting in R. R package, version 1.1." [Software Resource: http://ncslaap.lib.ncsu.edu/tools/norm/ ]

Kortmann, B. 2005. "Chapter V: Contrastive Linguistics: English and German". In B. Kortmann. 2005. Linguistics: Essentials. Berlin: Cornelsen, 156-191.

Krashen, S. 1985. The Input Hypothesis: Issues and Implications. New York: Longman.

Kuhl, P.K. 1991. "Human adults and human infants exhibit a perceptual magnet effect for the prototypes of speech sounds, monkeys do not." Perception and Psychophysics 50: 93-107.

Kuhl, P.K. 1993. "Early linguistic experience and phonetic perception: implications for theories of developmental speech perception." Journal of Phonetics 21: 125-139.

Major, R. C. 2008. "Transfer in second language phonology. A review." In: Hansen Edwards and Zampini, eds. 2008: 63-94.

Labov, W., S. Ash and C. Boberg. 2006. The Atlas of North American English. Berlin: Mouton-de Gruyter.

Schmidt, R. 1990. "The role of consciousness in second language learning." Applied Linguistics, 11, 129-158.

Schmidt, R. 1994. "Implicit learning and the cognitive unconscious: Of artificial grammars and SLA." In N. Ellis, ed. Implicit and Explicit Learning of Languages. London: Academic Press, 165-209.

Schmidt, R. 1995. "Consciousness and foreign language learning: A tutorial on the role of attention and awareness in learning." In R. Schmidt, ed. Attention and Awareness in Foreign Language Learning. Honolulu, HI: University of Hawaii, Second Language Teaching \& Curriculum Center, 1-63.

Schmidt, R. 2001. "Attention." In P. Robinson, ed. Cognition and Second Language Instruction. Cambridge: Cambridge University Press, 3-32. 
Schmidt, R. 2010. "Attention, awareness, and individual differences in language learning". In W. M. Chan, S. Chi, K. N. Cin, J. Istanto, M. Nagami, J. W. Sew, T. Suthiwan and I. Walker. Proceedings of CLaSIC 2010, Singapore. Singapore: National University of Singapore, Centre for Language Studies, 721-737.

Schmidt, R. and S.N. Frota. 1986. "Developing basic conversational ability in a second language: A case study of an adult learner of Portuguese." In R. R. Day, ed. Talking to Learn: Conversation in Second Language Acquisition. Rowley, MA: Newbury House, 237-326.

Selinker, L. 1972. "Interlanguage". International Review of Applied Linguistics 10, 209231.

Strange, W. 2007. "Cross-language phonetic similarity of vowels. Theoretical and methodological issues." In O.-S. Bohn and M.J. Munro, eds. 2007. Language Experience in Second Language Speech Learning. In Honor of James Emil Flege. Amsterdam and Philadelphia: John Benjamins, 35-56.

Strange, W. and V.L. Shafer. 2008. "Speech perception in second language learners: The re-education of selective perception." In: Edwards and Zampini, eds. 2008: 153-192.

Strange, W. ed. 1995. Speech Perception and Linguistic Experience: Issues in CrossLanguage Research, Baltimore: York Press.

The R Project for Statistical Computing. No date. "R". [www.r-project.org/, accessed 31/06/2011].

Thomas, E. R. and T. Kendall. 2007. NORM: The vowel normalization and plotting suite. [http://ncslaap.lib.ncsu.edu/tools/norm/, accessed: 07/06/2012].

Traunmüller, H. 1997. "Auditory scales of frequency representation". [http://www2.ling.su.se/staff/hartmut/bark.htm, accessed: 07/06/2012].

Wells, J.C. 1982. Accents of English. Cambridge, Cambridge University Press. 